\title{
Structural biology of Helicobacter pylori type IV secretion system
} Alessandro Angelini*1,2, Laura Cendron 1,2, Anke Seydel 1,2, Nicola Barison², Tommaso Tosi ${ }^{2}$, Roberto Battistutta ${ }^{1,2}$ and Giuseppe Zanotti ${ }^{1,2}$

\author{
Address: ${ }^{1}$ Venetian Institute of Molecular Medicine (VIMM), Padua, Italy and ${ }^{2}$ Department of Chemistry, University of Padua, Padua, Italy \\ * Corresponding author
}

\author{
from The 4th Recombinant Protein Production Meeting: a comparative view on host physiology \\ Barcelona, Spain. 2I-23 September 2006 \\ Published: 10 October 2006 \\ Microbial Cell Factories 2006, 5(Suppl I):P45 doi:I0.II86/1475-2859-5-SI-P45
}

(C) 2006 Angelini et al; licensee BioMed Central Ltd.

\section{Background}

Helicobacter pylori chronically infects the gastric mucosa of millions of people annually worldwide: it has been estimated that over $50 \%$ of the world population carries this infection. H. pylori has been associated with the development of several diseases, like chronic gastritis, gastric and duodenal ulcer, gastric adenocarcinoma and mucosaassociated lymphoma [1-3].

The complete genome sequence of two different isolates of H. pylori (J99 and 26995) is known. The strains that contain a $37 \mathrm{~kb}$ foreign DNA region, called cag pathogenicity island (cag-PAI), cause the most severe form of virulence [4].

The cag-PAI encodes for a functional type IV secretion apparatus homologous to the VirB/D4 Type IV Secretion System (T4SS) of the plant pathogen Agrobacterium tumefaciens and other Gram-negative bacteria [5]. T4SSs are involved in conjugal DNA transfer, in the DNA delivery to (or uptake from) the environment, for instance the release of oncogenic DNA into infected plant cells by A. tumefaciens, or in the translocation of effector proteins $[6,7]$.

The T4SS encoded by the cag-PAI of $H$. pylori is responsible for the translocation into the host cell of the protein CagA, a major antigenic virulence factor encoded within the cagPAI. Once secreted into the gastric epithelial cells, CagA induces cellular modifications, such as elongation and spreading of host cells [8].
The aim of this structural genomic project is to determine the three-dimensional structure of most of the proteins encoded by the cag-PAI, a task that will allow to elucidate the function and the organization of the entire T4SS of such a relevant pathogenic bacterium [9].

\section{Results}

Protein production for structural studies presents one of the most difficult and challenging tasks for heterologous expression in E. coli. Generally, the protein must be native, active, soluble, highly pure, and concentrated. We have identified protein insolubility/aggregation as the major bottlenecks in the process towards the determination of protein structures by X-ray diffraction. Each protein often needs separate handling and analysis to determine tag choice, growth and buffer conditions for optimal solubility. To speed up recombinant protein production, we have adopted a strategy of parallel expression of a protein from a variety of vectors containing different tags and/or fusion partners, and a variety of $E$. coli host strains.

To this point in time, we have cloned, expressed, and purified several proteins of the cag pathogenicity island of $H$. pylori. They all have been expressed in E. coli. We have already determined the structure of CagZ [10] and CagS, using the Se-Met method. We have also obtained crystals of an other protein, along with crystallization tests on other cag proteins. 


\section{Perspectives}

We believe these studies will also furnish valuable information for vaccine production and provide insights into the mechanism of $H$. pylori pathogenesis.

\section{References}

I. Covacci A, Telford JL, Del Giudice G, Parsonnet J, Rappuoli R: Helicobacter pylori virulence and genetic geography. Science 1999 , 284:1328-1333.

2. Moss SF, Sood S: Helicobacter pylori . Curr Opin Infect Dis 2003, 16:445-451.

3. Moss SF, Blaser MJ: Mechanisms of disease: Inflammation and the origins of cancer. Nat Clin Pract Oncol 2005, 2:90-97.

4. Akopyants NS, Clifton SW, Kersulyte D, Crabtree JE, Youree BE, Reece CA, Bukanov NO, Drazek ES, Roe BA, Berg DE: Analyses of the cag pathogenicity island of Helicobacter pylori. Mol Microbiol 1998, 28:37-53.

5. Bourzac KM, Guillemin K: Helicobacter pylori -host cell interactions mediated by type IV secretion. Cell Microbiol 2005, 7:911-919.

6. Cascales E, Christie PJ: The versatile bacterial type IV secretion systems. Nat Rev Microbiol 2003, I:137-149.

7. Christie PJ, Atmakuri K, Krishnamoorthy V, Jakubowski S, Cascales E: Biogenesis, architecture, and function of bacterial type IV secretion systems. Annu Rev Microbiol 2005, 59:45 I-485.

8. Hatakeyama M, Higashi H: Helicobacter pylori CagA: a new paradigm for bacterial carcinogenesis. Cancer Sci 2005, 96:835-843.

9. Remaut H, Waksman G: Structural biology of bacterial pathogenesis. Curr Opin Struct Biol 2004, 14:161-170.

10. Cendron L, Seydel A, Angelini A, Battistutta R, Zanotti G: Crystal structure of CagZ, a protein from the Helicobacter pylori pathogenicity island that encodes for a type IV secretion system. J Mol Biol 2004, 340:88I-889.

Publish with Bio Med Central and every scientist can read your work free of charge

"BioMed Central will be the most significant development for disseminating the results of biomedical research in our lifetime. "

Sir Paul Nurse, Cancer Research UK

Your research papers will be:

- available free of charge to the entire biomedical community

- peer reviewed and published immediately upon acceptance

- cited in PubMed and archived on PubMed Central

- yours - you keep the copyright

Submit your manuscript here:

http://www.biomedcentral.com/info/publishing_adv.asp 